\title{
Authentic experiential work in the socialisation of undergraduate students: an EHEA-framed epistemological consideration
}

\section{Robert Martínez Carrasco ${ }^{a}$}

${ }^{\text {aa } D e p a r t m e n t ~ o f ~ T r a n s l a t i o n ~ a n d ~ I n t e r p r e t a t i o n ~ a t ~ J a u m e ~ I ~ U n i v e r s i t y ~(S p a i n) ~}$

\begin{abstract}
The European Higher Education Area (EHEA) is adamant about the role of employability in curriculum development and the overall education process of undergraduate students. This responds not only to the current emerging models of economic and social growth but also to an underlying epistemological shift regarding the very nature and characteristics of Education. This article provides the epistemological foundation of the said shift, arguing, from a post-positivist perspective, how authentic experiential work in the classroom may contribute to the progressive socialisation of students into their respective communities of practice, thus bridging the gap between the labour market and the education institutions.
\end{abstract}

Keywords: experiential work; collaborative work; classroom methodology; epistemology; emergentism; higher education 


\section{Introduction}

The progressive socialisation of graduates in their respective communities of practice is regarded, these days, as one of the main goals in the education process of undergraduate students. Becoming an 'expert' in their field, following the Dreyfus and Dreyfus (1980) model of expertise, implies bringing professionals-to-be from the periphery of their respective professional community to its very centre, advancing from the 'novice' stage all the way through their education process (González-Davies \& Enríquez-Raído, 2016). Indeed, Risku (2010:105) reminds of the importance, in educational settings, of paying appropriate attention to the actor-network relations in the profession, since, at the end of the day, the functioning and internal rules of a socio-professional community, Marco adds (2016:34), depend exclusively on its members.

The assumption reflected above, which is widely accepted at present and understood to be rather obvious in tertiary education, implies a particular epistemological stance that embraces a number of post-positivist premises, namely Deweyan, insofar it believes that "education is not preparation for life, it is life itself" (Duffy \& Cunningham, 1996:4). Thus, the learning activity, analysed in Deweyan terms, results from the interaction of meaningful, important experiences within the learner, and thus their needs and interests as future members of the relevant communities of practice is believed to stand as one of the cornerstones of any third level educational approach.

Yet, the professionals in charge of those education processes rarely possess the relevant pedagogical background. Quite on the contrary, they are expected to know how to teach, how to guide the education process of their students and have an active role in curriculum development, lesson planning, etc. (Kiraly, 2014), which leaves lecturers in a rather 'swim or sink' situation in their classrooms while "more attention is paid, for example, to their training as researchers in their discipline" (Kelly, 2008:108). It may come as no surprise, then, that the absence in many cases of a solid background in Educational Philosophy and Pedagogy may result in a rich plethora of pedagogical perspectives and educational aims with various, sometimes even over-lapping, epistemological (unconscious?) beliefs. This 'common sense epistemology' (Bereiter \& Scardamaglia, 1993), based on intuition, observation, imitation or even perpetuation of teaching practices, may be said to be the basis of a significant part of our current teaching and learning classroom methodology.

One could wonder how this methodological and epistemological hotchpotch has somehow accepted the current common belief regarding not only the importance of Dewey's 'learnby-doing', but also the role of experiential work and the student-centred nature of Education. Indeed, contemporary educational approaches cannot be separated from postpositivist grounds, namely constructivist, even if the degree of the implementation of those post-positivist ideals may vary from field to field, and from lecturer to lecturer, rendering a 
complex picture in terms of how we believe third level education should be, here and now, how it really is, and all the possibilities in between.

The irruption of the European Higher Education Area (EHEA) has indeed contributed significantly to the shift in the mainstream third level education paradigm. As we have argued elsewhere (Martínez-Carrasco, in press), EHEA has re-modelled degree programmes, classroom methodologies, assessment procedures, and even the very role of students and educators in an attempt to "build upon its intellectual, cultural, social, scientific, and technological dimensions" (Bologna Declaration, 1999:1-2). The EHEA structure, framing tertiary education and providing the relevant legal and institutional grounds, has served effectively to spread and promote the current epistemological third level education scenario.

\section{Current educational epistemologies: a situated hagiography}

The nature of knowledge itself and knowledge acquisition may be roughly ascribed to three major epistemological stances shaping the idiosyncrasy of the teaching profession (Davis \& Sumara, 2004; Doll, 2002): empirico-rationalist approaches, constructivist approaches and emergentist approaches. While the first one seems to be have been condemned to public scorn these days insofar it is believed to represent traditional educational ideas based on lecturer-centred performance, memorisation and recitation, one needs to acknowledge the relevant role these positivist trends have played and still play in Education. At the end of the day, as Kiraly recognises (2016:53), it is just a matter of the way reality is conceptualised, so no epistemological approach may present any claim to universal truth but rather a situated contextualisation of the affairs. The said opinion is shared by a number authors who claim the validity of mixed, eclectic epistemological stances to be applied to third level education (Kinchin \& Hay, 2007:4; Cronjé, 2006:393)

In contrast, the constructivist epistemological spectrum has gained momentum in educational settings, at first on earlier stages of education and since the implementation of EHEA also in tertiary education. EHEA finds in constructivism the epistemological backbone of some of its main objectives, namely employability and lifelong learning (Commission/EACEA/Eurydice, 2015). Through the constructivist perspective, education becomes learning (Biesta, 2013b) since the underlying rationale it presents assumes that the learning activity occurs within the cognition of the individual, who makes sense of the world when contrasting their cognitive structures to the reality outside them. It is thus the cognising agent (von Glasersfeld, 2005) who, as a result, 'builds up' particular cognitive structures, be it through social interaction (hence the 'social' tag of constructivism) or within one's own cognition (Piaget's 'radical' brother of social constructivism).

One of the ways EHEA articulates its epistemological stance towards better employability of the European graduates is the use of competences, traditionally applied to vocational 
training given its more professionally-oriented nature (Halász \& Michel, 2011:289). If employability is to be one of the main goals of third level education, then formulating the respective learning outcomes in terms of competences, skills, and abilities makes complete sense as opposed to the traditional knowledge attainment criteria. Indeed, the current emerging models of economic and social growth explored by Biesta (2013a) and De Ketele (2008), among others, reflect the use of competences in a post-positivist environment as a tool to bring the labour market closer to university education, hence the fundamental role of experiential work embedded in the curriculum.

The main tenets of these post-positivist trends are summarised by Doolitle and Hicks (2003) and contemplate the individual and socially-mediated nature of the learning activity, the importance of authentic and real world environments, the role of the learner's prior knowledge and experience, and the self-regulated, self-mediated, self-aware nature of the construction of knowledge. This conceptualisation of learning reflects the degree of complexity of cognitive development and calls for particular adaptation, self-organisation, and interaction processes in the education of undergraduate students. In fact, the perks of socially-mediated learning embedded in authentic environments have been highlighted by many (Robinson et al, 2016) as a unique channel for lecturers to push the boundaries of their students' cognitive actual development level, using Vygotskian terms.

\subsection{The irruption of Emergentism}

Authors like Doolittle (2014) have integrated the characteristics of complex thinking, which has become increasingly popular in the last 30 years (Davis \& Sumara, 2008:35) into a constructivist model, and speak of 'complex constructivism', or 'emergentism', advising that complexity stands as "a broad-based theory concerning the evolution and functioning of non-linear systems that may be applied in many domains", education included (Doolitle, 2014:490). Indeed, emergentism allows to understand education as a complex, transdisciplinary activity and provides a fresh insight on questions such as sense-making, teacher-learner relationships, classroom dynamics, etc. (Davis \& Sumara, 2008:34).

Kiraly (2016:61) sheds light on the matter speaking of the nature of complex and complicated systems regarding the emergentist epistemological grounds. Emergentism, he asserts, understands complex systems as something beyond the sum of its parts, something with emergent properties. Learning, as Davis and Sumara point out (2004:101) "is not about acquisition, processing or storing, but about emergent structuring”. Similarly, De Bot et al (2007:7), in the context of Dynamic Systems Theory and its application to educational settings, speak of the difficulty of education insofar systems (here, cognitive structures) are constantly changing, developing through interaction with the environment and through processes of internal reorganisation. 
Cognition, understood as a complex system, allows for mind-as-a-brain conceptualisations, something in constant construal and re-organisation, as opposed to the traditional constructivist mind-as-a-computer metaphor. Some even speak of shared cognition and mind-as-a-rhizome interpretations (Duffy \& Cunningham, 1996:8), claiming that cognition may be socially shared and stored, removing it from the actual individual. This very last metaphor is remarkably interesting insofar it follows that the learning process may be nothing but a "dialogue and negotiation with and within a local sociocultural context" (ibid:12), where authentic, experiential work embedded in collaborative projects may play a crucial role.

\section{Implications in classroom methodology}

Building on the epistemological shift argued above, it comes as no surprise that the new epistemological stances have required a different approach in the teacher-learner relations, but also in class methodology and the way the curriculum is drafted, presented, and applied in contemporary classrooms. From an apparently old-fashioned positivist, teacher-centred methodology, the current institutional framework pushes lecturers to bring students to the very centre of their learning activity, and thus promote their emancipation as individuals and their progressive socialisation into their communities of practice. To that concern, Kiraly (2000:22) welcomes the epistemological discussion above since it promotes further debate on pedagogy and educational implications. Besides, the scholar puts forward a number of classrooms models: from a transmissionist, teacher-controlled positivist model to a transformative, student-controlled model where the role of lecturers becomes that of a facilitator of the overall learning activity, in charge of the scaffolding (again, Vygotskian terms) of the education process of their students. To those models González-Davies and Enríquez-Raído (2016:7) add a fourth one, a 'transactional' model, which serves to bridge both epistemological stances.

García (2016:101), on post-positivist teaching methodologies, speaks of the authenticity of the learning activity and its context as an integral part of knowledge and effective learning outcomes, suggesting a project-based collaborative methodology that addresses real life situations. As the scholar argues, project-based learning, grounded in post-positivist epistemological approaches, presents an interesting number of characteristics promoting both the socialisation of students in their respective communities of practice and the current EHEAn quest for employability: authenticity (real problems, effective solutions), complexity (students are faced with complex matters relying on a number of variables), construction research and use of tools (researching, planning, implementing, reporting), autonomy (and subsequent responsibility). To that list one could add motivation, since the use of authentic materials in a project-based methodology tends to have a significant impact in the overall satisfaction of students, who see how 'reality' enters their classrooms and their project are vested with the legitimacy and liability of real-life affairs. 
Regarding the way to integrate the use of authentic experiential work in the classroom, be it in a project-based fashion or any other methodological approach, González-Davis and Enríquez-Raído (2016:3) find three main common trends: approaches where students are presented in the classroom with a realistic task based on collaborative work, approaches where students engage real-life professional work through work placements and schemes (outside the classroom), and approaches where the previous methodologies are combined.

All in all, emergentism understands education as a situated, context-dependent activity (Risku, 2016:101), hence the importance that lecturers implement authentic or nearauthentic tasks into their teaching, preferably in collaboration-based settings. Under this emergentist paradigm, it is only though real, significant assignments embedded in authentic situations that students are exposed to the complexity and constraints a professional in their field would meet in the course of their career (see Kiraly, 2016, for an extensive contribution on the use of authentic materials in the education of translators, for instance).

\subsection{The socialisation of students under emergentist premises}

EHEA's employability standards require that university lecturers go a step further away from their classic transmissionist role and make sure that their students develop the relevant knowledge, skills, and abilities that professionals in their field display, but also a sense of the idiosyncratic identity of their community of practice, the explicit and hidden norms, behaviour and values, sense of belonging, professional self-concept, etc.

Emergentism, as well as other post-positivist epistemological standpoints, does provide the ideal breeding ground for those aspirations to take place, understanding cognition, and therefore Education, as a complex entity with emergent properties. Under the emergentist paradigm, activities, tasks, and projects are understood in a situated, dynamic context that serves students to grown professionally and personally in an empowering education continuum that does fill the gap between the labour world and the education institutions.

As Risku acknowledges (2016:6), the use of authentic materials may indeed stand as the right vehicle to achieve the socialisation of students since it allows them to take full responsibility of their education process "gaining competence, especially when they take part in a dialogue and can assume a meaningful role in an authentic situation". 


\section{References}

Bereiter, C., \& Scardamaglia, M. (1993). Surpassing Ourselves: An Inquiry into the Nature and Explications of Expertise. Chicago \& Lasalle: Open Court.

Biesta, G. (2013a). Interrupting the Politics of Learning. Power and Education, 5(1), 4.

Biesta, G. (2013b). Receiving the gift of teaching: From "learning from" to "being taught by." Studies in Philosophy and Education, 32(5), 449-461.

Commission/EACEA/Eurydice, E. (2015). The European Higher Education Area in 2015: Bologna Process Implementation Report. Luxembourg: Publications Office of the European Union.

Cronjé, J. C. (2006). Paradigms Regained: Towards Integrating Objectivism in Instructional Design and the Learning Sciences. Educational Technology Research and Development, 54(4), 387-416.

Davis, B., \& Sumara, D. (2004). Inventions of Teaching: A Genealogy. Mahwah: L. Earlbaum Associates.

Davis, B., \& Sumara, D. (2008). Complexity as a theory of education. TCI (Transnational Curriculum Inquiry), 5(2), 33-44.

De Bot, K., Lowie, W., \& Verspoor, M. (2007). A Dynamic Systems Theory approach to second language acquisition. Bilingualism: Language and Cognition, 10(1), 7-21.

De Ketele, J. M. (2008). Enfoque socio-histórico de las competencias en la enseñanza. Revista de Currículum Y Formación Del Profesorado, 12(3), 1-12.

Doll, W. E. (2002). Ghosts and the Curriculum. In W. E. Doll \& N. Gough (Eds.), Curriculum Visions. New York: Peter Lang.

Doolitle, P., \& Hicks, D. (2003). Constructivism as a theoretical foundation for the use of technology in social studies. Theory and Research in Social Education, 31(1), 72-104.

Doolittle, P. (2014). Complex Constructivism: A Theoretical Model of Complexity and Cognition. International Journal of Teaching and Learning in Higher Education, 26(3), 485-498.

Dreyfuss, S. E., \& Dreyfus, H. L. (1980). A five-stage model of the mental activities involved in directed skill acquisition. Operations Research Center, (February), 1-18.

Duffy, T. M., \& Cunningham, D. J. (1996). Constructivism: Implications for the Design and Delivery of Instruction. Handbook of Research for Educational Communications and Technology, 171(4), 1-31.

García, C. (2016). Project-based Learning in Virtual Groups - Collaboration and Learning Outcomes in a Virtual Training Course for Teachers. Procedia - Social and Behavioral Sciences, 228 (June), 100-105

Glasersfeld von, E. (2005). Introduction: Aspects of constructivism. In C. T. Fosnot (Ed.), Constructivism: Theory, Perspectives and Practice. New York: Columbia University Press.

González-Davies, M., \& Enríquez-Raído, V. (2016). Situated learning in translator and interpreter training: bridging research and good practice. The Interpreter and Translator Trainer, 417 (August) 
Halász, G., \& Michel, A. (2011). Key competences in Europe: Interpretation, policy formulation and implementation. European Journal of Education, 46(3), 289-306.

Kelly, D. (2008). Training the Trainers: Towards a Description of Translator Trainer Competence and Training Needs Analysis. TTR: Traduction, Terminologie, Rédaction, 21(1), 99-125.

Kinchin, I., \& Hay, D. (2007). The myth of the research-led teacher. Teachers and Teaching, 13(1), 43-61

Kiraly, D. (2000). A Social constructivist approach to translator education : Empowerment from theory to practice. Manchester, UK: St. Jerome

Kiraly, D. (2014). From Assumptions about Knowing and Learning to Praxis in Translator Education. inTRAlinea, (Special Issue: Challenges in Translation Pedagogy), 1-11.

Kiraly, D. (2016). Towards Authentic Experiential Learning in Translator Education. Mainz: V\&R Press

Marco, J. (2016). On the margins of the profession: the work placement as a site for the literary translator trainee's legitimate peripheral participation. The Interpreter and Translator Trainer, 417(August).

Martínez-Carrasco, R. (in press) The politics of learning within post-Yerevan EHEA: Some epistemological remarks on the role of university lecturers in Forum de Recerca XXI

Risku, H. (2010). A cognitive scientific view on technical communication and translation: Do embodiment and situatedness really make a difference? Target, 22(1), 94-111.

Risku, H. (2016). Situated learning in translation research training: academic research as a reflection of practice. The Interpreter and Translator Trainer, 417(May), 1-17.

Robinson, B., Olvera-Lobo, M. D., \& Gutiérrez-Artacho, J. (2016). After Bologna: Learner- and Competence-Centred Translator Training for "Digital Natives." In C. Martín de León \& V. González-Ruiz (Eds.), From the Lab to the Classrom and Back Again: Perspectives on Translation and Interpreting Training (pp. 325-359). Bern: Peter Lang. 